\title{
Hantavirus pulmonary syndrome and rodent reservoirs in the savanna-like biome of Brazil's southeastern region
}

\author{
J. E. LIMONGI ${ }^{1}$, R. C. OLIVEIRA ${ }^{2}$, A. GUTERRES ${ }^{2}$, S. F. COSTA NETO ${ }^{3}$, \\ J. FERNANDES ${ }^{2}$, L. H.B. VICENTE ${ }^{2}$, M. G. COELHO ${ }^{4}$, V. N. RAMOS ${ }^{4}$, \\ M. S. FERREIRA ${ }^{5}$, C. R. BONVICINO ${ }^{3}$, P. S. D'ANDREA ${ }^{3}$ AND E. R. S. LEMOS ${ }^{2}$ \\ ${ }^{1}$ Curso de Saúde Ambiental, Instituto de Geografia, Universidade Federal de Uberlândia, Uberlândia, Brazil \\ ${ }^{2}$ Laboratório de Hantaviroses, Fundação Oswaldo Cruz, Instituto Oswaldo Cruz, Rio de Janeiro, Brazil \\ ${ }^{3}$ Laboratório de Biologia e Parasitologia de Mamíferos Silvestres Reservatórios, Fundação Oswaldo Cruz, \\ Instituto Oswaldo Cruz, Rio de Janeiro, Brazil \\ ${ }^{4}$ Laboratório de Ixodologia, Faculdade de Medicina Veterinária, Universidade Federal de Uberlândia, \\ Uberlândia, Brazil \\ ${ }^{5}$ Departamento de Moléstias Infecciosas, Faculdade de Medicina, Universidade Federal de Uberlândia, \\ Uberlândia, Brazil
}

Received 7 May 2015; Final revision 13 August 2015; Accepted 11 September 2015; first published online 6 October 2015

\section{SUMMARY}

This paper describes the diversity of rodent fauna in an area endemic for hantavirus cardiopulmonary syndrome (HCPS) in Brazil, the population dynamics and the relationship of rodents with hantavirus in the Cerrado (savanna-like) biome. Additionally, an analysis is made of the partial S segment sequences of the hantaviruses obtained from serologically confirmed human HCPS cases and from rodent specimens. Rodents were collected during four campaigns. Human serum samples were collected from suspected cases of HCPS at hospitals in the state of Minas Gerais. The samples antibody-reactive by ELISA were processed by RT-PCR. The PCR product was amplified and sequenced. Hantavirus was detected only in Necromys lasiurus, the wild rodent species most prevalent in the Cerrado biome (min-max: 50-83.7\%). All the six human serum samples were hantavirus seropositive and five showed amplified PCR products. The analysis of the nucleotide sequences showed the circulation of a single genotype, the Araraquara hantavirus. The environmental changes that have occurred in the Cerrado biome in recent decades have favoured $N$. lasiurus in interspecific competition of habitats, thus increasing the risk of contact between humans and rodent species infected with hantavirus. Our data corroborate the definition of $N$. lasiurus as the main hantavirus reservoir in the Cerrado biome.

Key words: Araraquara virus, hantavirus pulmonary syndrome, Necromys lasiurus, Rodentia.

\section{INTRODUCTION}

Hantavirus cardiopulmonary syndrome (HCPS) is a potentially fatal zoonosis caused by hantaviruses

\footnotetext{
* Author for correspondence: Dr J. E. Limongi, Av. João Naves de Ávila, 2121, Bloco 1H, Sala 23, 38400-902 Uberlândia, MG, Brazil. (Email: jeanlimongi@gmail.com)
}

(family Bunyaviridae, genus Hantavirus) described in the Americas. These viruses are associated mainly with rodents of the family Cricetidae, more specifically the subfamilies Sigmodontinae and Neotominae [1, 2]. However, with the expansion of studies on wildlife diseases, other animals infected with hantavirus have been identified, such as bats, shrews and moles in Asia, Africa and Europe [3]. In South America, the 
first evidence was described in bats and opossums in the state of São Paulo, Brazil [4]. More than 1780 HCPS cases have been confirmed in Brazil since 1993, with the second highest incidence in the state of Minas Gerais (258 cases), where the majority of HCPS cases are confirmed by means of serological assays that do not identify a specific aetiological agent $[5,6]$.

Several rodent species in the Americas are reservoirs of different hantavirus genotypes, with high levels of specificity among them [7]. However, many hantaviruses have been identified in more than one host, and additional studies are required to clarify the roles of host specificity, spillover, host-jumping and co-speciation with respect to hantavirus-host association [3]. Seven hantavirus genotypes are often associated with HCPS in Brazil: Juquitiba, Araraquara, Paranoa, Laguna Negra, Castelo dos Sonhos, Rio Mamoré and Anajatuba. Three other genotypes, Rio Mearim, Jaborá, and Seoul-like, have been identified in rodents, but an association with human disease has not yet been established [3, 7, 8]. Araraquara virus (ARQV) is a genotype of clade III of Andes virus (ANDV), as is Paranoa virus, and both circulate in central Brazil [9-11].

The rodent species Necromys lasiurus is considered the main reservoir of ARQV and is endemic throughout the Cerrado (savanna-like), Caatinga and along the Atlantic Forest-Cerrado ecotone [3, 12]. ARQV has been identified across the dry northern Cerrado region to the edge of the Atlantic rainforest in Brazil's southeastern region. Studies in this area have demonstrated that ARQV is considered the most virulent genotype and asymptomatic infections are relatively frequent. ARQV has a high fatality rate that may reach up to $50 \%[5,12,13]$.

Juquitiba virus (JUQV), a genotype of clade IV of ANDV that occurs in the Atlantic rainforest and Araucaria subtropical forest environments in Brazil's southern states, was recently identified in the states of Mato Grosso do Sul, associated with Oligoryzomys mattogrossae (specimens found in the Cerrado and Caatinga domains, previously identified as $O$. fornesi, are here considered as $O$. mattogrossae) [14] and Minas Gerais, from HCPS cases, both regions comprising Cerrado environment [6, 9, 15]. There is a need to clarify which reservoir host is involved in human cases caused by JUQV in the Cerrado, since the main reservoirs of this virus are the rodent species Oligoryzomys nigripes, which is not abundant in this biome, and O. mattogrossae.
Rodents were captured in different phytophysiognomies of the Cerrado (Savanna-like) biome in order to identify the diversity of these mammal fauna, their population dynamics and their relationship with hantavirus. Additionally, an analysis was made of the partial S segment sequences of the hantaviruses obtained from serologically confirmed human HCPS cases and from rodent specimens in an endemic area in the state of Minas Gerais, Brazil.

\section{METHODS}

\section{Study area}

The study on humans was conducted from December 2011to November 2012 in the HCPS endemic area in the state of Minas Gerais, southeastern Brazil (Fig. 1). This entire area lies within the Cerrado biome, which is characterized by scrub vegetation adapted to long periods of drought, but which is undergoing varying degrees of degradation. The region is characterized by a subtropical climate with two well-defined seasons: a dry winter (May-September) and a rainy summer (OctoberApril). The mean annual temperature and rainfall are $22{ }^{\circ} \mathrm{C}$ and $1650 \mathrm{~mm}$, respectively. The rodent study was performed in the municipality of Uberlândia $\left(18^{\circ}\right.$ $55^{\prime} 07^{\prime \prime} \mathrm{S}, 48^{\circ} 16^{\prime} 38^{\prime \prime} \mathrm{W}$, Greenwich meridian) in regions with different Cerrado physiognomies [16].

\section{Samples}

\section{Rodents}

Rodents were captured and handled according to recommended safety procedures [17]. These mammals were trapped during four campaigns between December 2011 and November 2012, and the trapping effort amounted to a total of 4700 trap-nights. Sherman and Tomahawk traps were used in a 4:1 ratio. Trapping success was calculated as the number of captured animals per trapping effort multiplied by 100 , where the trapping effort is the number of traps set multiplied by the number of nights of capture. At the moment of capture, the date and capture site, external measurements, body size, weight, sex, reproductive status and presence of scars of each rodent specimen were recorded. Each animal was anaesthetized and euthanized by intramuscular injection of ketamine hydrochloride (Ketalar ${ }^{\circledR}$ Laboratorio ELEA S.A.C.I.F. y A., Argentina), based on an anaesthetic protocol according to allometric scaling [18]. Blood was drawn by cardiac puncture from 


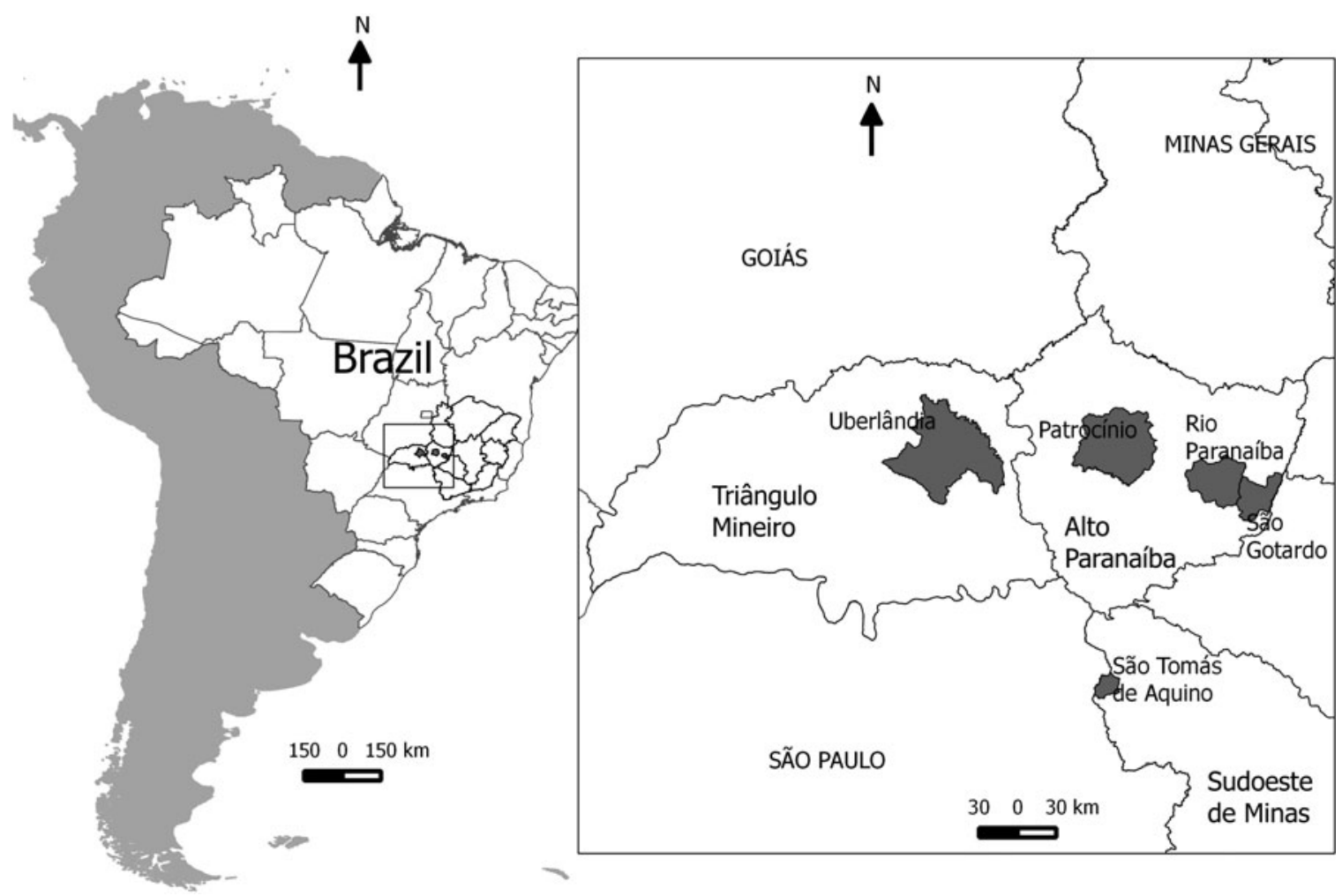

Fig. 1. Location of the study area in Brazil (box) and detail of area showing municipalities.

each anaesthetized rodent. Sera and tissue samples of liver, spleen, kidney, lung, and heart were collected and stored immediately in liquid nitrogen for further processing. All the collected specimens were scarified and fixed in $10 \%$ formalin, or prepared as skin and skull, and deposited as voucher specimens at the National Museum of the Federal University of Rio de Janeiro. Age structures of the most abundant species were based on body weight ( $\mathrm{g}$ ) and sex, and the individuals were divided into three groups [19]. Age groups of Necromys lasiurus were divided as follows: males [group I (younger) $\leqslant 29 \mathrm{~g}$, group II (adult) $30-50 \cdot 5 \mathrm{~g}$, group III (older) $\geqslant 50.6 \mathrm{~g}$ ], females (group I $\leqslant 27 \mathrm{~g}$, group II $28-45 \mathrm{~g}$, group III $\geqslant 46 \mathrm{~g}$ ).

Most of the species were identified based on an external morphological analysis [20]. Cryptic rodent species taxonomy was confirmed by karyotypic analysis [21]. DNA sequence data of the mitochondrial gene cytochrome $b$ were also analysed to confirm species identification of specimens without cell material for karyotypic analysis, following standard procedures [22]. Cytochrome $b$ gene ( $1140 \mathrm{bp})$ was amplified with L14724 [23] and MVZ 14 primers [24] and sequenced with the same primers, in addition to Citb-Sot-in1 and Citb-Sot-in2 [25] in an ABI
PRISM 377 automatic DNA sequencer (Applied Biosystems, USA).

\section{Humans}

Serum samples, which were collected from suspected HCPS cases at hospitals after the onset of symptoms, were immediately placed in liquid nitrogen $\left(-196^{\circ} \mathrm{C}\right)$ and then stored in an ultrafreezer $\left(-80^{\circ} \mathrm{C}\right)$. All the samples were tested at the Regional Hantavirus Reference Laboratory of the Oswaldo Cruz Foundation in Rio de Janeiro, RJ, Brazil.

\section{Serological tests}

The human serum samples were analysed by ELISA, using an IgM kit from Hantec (Carlos Chagas Institute, ICC/Fiocruz-PR), according to the manufacturer's protocol [26].

Rodent serum samples were examined for $\operatorname{IgG}$ antibodies against the recombinant Araraquara nucleocapsid protein used as the specific antigen by ELISA. The IgG ELISA was performed by coating a microtitre plate with an N-ARA antigen and a negative control antigen overnight at $37^{\circ} \mathrm{C}$. After washing 
and blocking the plate with $0 \cdot 1 \%$ PBS-Tween 20 and $5 \%$ dry milk, serum samples were added. IgG antibodies was detected in rodent sera diluted 1:400 using peroxidase-labelled affinity-purified IgG antibody anti-Peromyscus leucopus and anti-rat conjugate for Rattus rattus. The chromogenic substrate used was $2 \cdot 2$ '-azino-di-(3-ethylbenzthiazoline sulfonate), and absorbance was measured at $405 \mathrm{~nm}$. A serum dilution was considered positive if its optical density (OD) was $>0 \cdot 3$. The final OD of each dilution of serum sample was calculated as the difference between the OD values measured in wells coated with $\mathrm{N}-A R Q V$ protein and those coated with negative control antigen. A titre of $>1: 400$ was considered positive $[27,28]$.

\section{Characterization of hantavirus}

\section{Rodents}

The lung tissues of antibody-reactive rodents were subjected to viral RNA extraction using a PureLink kit (Invitrogen, USA), according to the manufacturer's instructions.

\section{Humans}

The serum samples from antibody-reactive patients were subjected to viral RNA extraction using a QIAamp Viral RNA mini kit (Qiagen, USA), according to the manufacturer's instructions.

\section{PCR}

One-step RT-PCR was performed, followed by seminested PCR. Amplification and sequencing were performed using specific primers for the nucleoprotein coding region of the $\mathrm{S}$ segment of the viral genome [29]. Amplicons of expected sizes (479 bp) were purified from agarose gel, using a Wizard $^{\circledR}$ Genomic DNA Purification kit (Promega, USA). The PCR product purified from the gel was sequenced using a commercial BigDye Terminator v. 3.1 cycle sequencing kit (Applied Biosystems). The nucleotide sequences were obtained in an ABI PRISM 3130x1 automated sequencer (Applied Biosystems). The nucleotide sequences and their sequencing electropherograms of the amplified fragments of genomic S segment were analysed using the MEGA 5.0 program [30]. A consensus sequence was established, and the divergences between the nucleotide sequences were clarified by analysing the sequencing electropherograms. This sequence was compared with a reference panel of sequences that comprises most of the American hantaviruses, for which there are at least $390 \mathrm{nt}$ sequences available in GenBank. Multiple sequence alignment and comparison of nucleotides were performed using MUSCLE, in the SeaView v. 4 software program (http://pbil.univ-lyon1.fr/software/ seaview). The phylogenetic relationships were estimated by the Markov Chain Monte Carlo (MCMC) method implemented in MrBayes v. 3.1.2 using the GTR $+G$ nucleotide substitution model [31]. The MCMC settings consisted of two simultaneous independent runs with four chains each, which were executed for 10 million generations and sampled every 100 generations, yielding 100000 trees. After eliminating $25 \%$ of the samples as burn-in, a consensus tree was built. Statistical support of the clades was measured by Bayesian posterior probabilities. Hantaan virus (NC005218) and Seoul virus (AY027040) sequences were used as outgroups for the analyses.

Nucleotide similarity among hantavirus partial $\mathrm{S}$ segment amplimers was determined, along with other GenBank sequences representing different hantavirus strains, using MegAlign v. 5.05 (DNASTAR Inc., USA).

\section{Statistical analysis}

The $\chi^{2}$ with Yates correction and Fisher's exact tests were applied for comparison between proportions, using Epi Info v. 3·5·4 (CDC, USA). Statistical significance was set at $5 \%(P \leqslant 0 \cdot 05)$.

\section{Ethical standards}

The authors state that all the procedures involved in this work are in compliance with the ethical standards of the pertinent national and institutional committees on human experimentation and with the Helsinki Declaration of 1975, as revised in 2008, and with institutional guidelines on the care and use of laboratory animals. The project was approved by the Ethics Committee for Human Research of the Oswaldo Cruz Institute in Rio de Janeiro. The patients' written consent was obtained. Permits for field collection were provided by IBAMA (Brazilian Institute of Environment and Renewable Natural Resources). Animal handling procedures were approved by the Animal Research Ethics Committee of the Federal University of Uberlândia. 
Table 1. Trapping success rate and seroprevalence for hantavirus in rodents in the municipality of Uberlândia, Minas Gerais, Brazil, 2011-2012

\begin{tabular}{|c|c|c|c|c|c|c|c|c|}
\hline $\begin{array}{l}\text { Trapping } \\
\text { period }\end{array}$ & Trap-nights & Captures & $\begin{array}{l}\text { Trapping } \\
\text { success }(\%)\end{array}$ & $\begin{array}{l}\text { Male } \\
(\%)\end{array}$ & $\begin{array}{l}\text { Female } \\
(\%)\end{array}$ & $\begin{array}{l}\text { Pregnant } \\
(\%)\end{array}$ & $\begin{array}{l}\text { No. } \\
\text { of } \\
\text { N1 }\end{array}$ & $\begin{array}{l}\text { Prevalence o } \\
\text { hantavirus } \\
\text { Nl }(\%)\end{array}$ \\
\hline December 2011 & 1200 & 27 & $2 \cdot 3$ & 56 & 44 & 42 & 15 & 0 \\
\hline March 2012 & 1100 & 13 & $1 \cdot 2$ & 23 & 77 & 70 & 6 & 0 \\
\hline August 2012 & 1200 & 184 & $15 \cdot 3$ & 52 & 48 & 0 & 145 & $2 \cdot 1$ \\
\hline November 2012 & 1200 & 34 & $2 \cdot 8$ & 53 & 47 & 7 & 15 & $6 \cdot 7$ \\
\hline Total & 4700 & 258 & $5 \cdot 5$ & $51 \cdot 6$ & $48 \cdot 4$ & 11 & 181 & $2 \cdot 2$ \\
\hline
\end{tabular}

$\mathrm{N} 1$, Necromys lasiurus.

\section{RESULTS}

\section{Rodents}

Two hundred and fifty-eight rodents were captured, $245(95 \%)$ in Sherman traps and $13(5 \%)$ in Tomahawk traps. Eleven taxa were identified to the species level and two to the generic level, all belonging to the subfamily Sigmodontinae (Tables 1 and 2). The most numerous species captured were $N$. lasiurus (181, $70 \cdot 1 \%$ ) and Calomys expulsus $(30,11 \cdot 6 \%)$. The phytophysiognomy of semi-deciduous dry forest was the most biologically diverse environment for Sigmodontinae. The total number of captured animals was directly related to climate condition, and this number was significantly higher in the dry season than in the wet season $(P<$ 0.0001) (Tables 1 and 2).

A larger number of males $(133,51 \cdot 6 \%)$ than females were captured. There was a higher prevalence of pregnancy in rainy summer periods than in the dry winter season $(P<0 \cdot 0001)$ (Table 1).

$N$. lasiurus was the main rodent found in all types of vegetation (min-max: 50-83.7\%). C. expulsus was found in four types of environment, but was absent from Brachiaria spp. (Table 2).

There was a predominance of individuals of age group III (older) during the rainy season $(60 \%)$. During the dry season, the number of individuals of age groups I and II corresponded to $85 \cdot 5 \%$, indicating a higher percentage of young individuals in the population during this period.

Four rodents were seroreactive (overall prevalence $1 \cdot 6 \%$ ). Only $N$. lasiurus had IgG antibodies to hantavirus ( $N$. lasiurus prevalence $2 \cdot 2 \%$ ) (Table 1$)$. Three $(75 \%)$ of the seroreactive animals were males and all seroreactive animals presented scars. Scarring was associated with the presence of antibodies to hantavirus $(P=0 \cdot 01$, Fisher's exact test). Fragments of S hantavirus genome segment were detected in three rodents
(Supplementary Fig. S1). Two sequences from the rodents [LBCE 18197 (Genbank: KT257178) and LBCE 17849 (Genbank: KT257177)] were obtained and subjected to phylogenetic analysis.

\section{Humans}

All patients suffering from HCPS were male, mean age $34 \cdot 6 \pm 14 \cdot 0$ years. The fatality rate of the cases was $60 \%$ (Table 3 ). The classic symptoms of fever, headache, dyspnoea, myalgia, and dizziness were observed in all cases. The time between the onset of symptoms and hospital admission was $4 \cdot 8 \pm 2 \cdot 1$ days.

With regard to risk activities, $85.7 \%$ of the patients had engaged in occupational or occasional farming activities up to 60 days before the onset of symptoms.

Human serum samples were collected on average 4 days after the onset of symptoms of six suspected HCPS cases. All were serologically confirmed HCPS cases and five showed amplified PCR products of expected size (Table 3).

\section{Phylogenetic analysis}

Phylogenetic analysis of nucleotide sequences of human and rodent samples showed only the circulation of the ARQV genotype (Fig. 2).

The sequenced rodent samples, from rural areas in the municipality of Uberlândia, exhibited a high phylogenetic identity with human sample LH_206_12 (Genbank: KT257181), with a well-supported cluster [posterior probability $(\mathrm{pp})=0.98$ ]. Samples of rodents, with human samples [LH_206_12 and LH_180_12 (Genbank: KT257179)], were more closely related to the Paranoa virus variant described in the federal district, located at a distance of about $463 \mathrm{~km}$ from the municipalities of Uberlândia and Patrocínio, than to the other cluster composed of three human samples 
Table 2. Number of rodent species captured according to each environment and species in Uberlândia, Minas Gerais, 2011-2012

\begin{tabular}{|c|c|c|c|c|c|c|}
\hline \multirow[b]{2}{*}{ Species } & \multicolumn{6}{|c|}{ Phytophysiognomy of Cerrado biome } \\
\hline & $\begin{array}{l}\text { Semi-deciduous } \\
\text { dry forest }\end{array}$ & $\begin{array}{l}\text { Flooded } \\
\text { gallery forest }\end{array}$ & $\begin{array}{l}\text { Brachiaria spp. } \\
\text { (altered Cerrado) }\end{array}$ & $\begin{array}{l}\text { Vereda (palm } \\
\text { swamps)/pasture }\end{array}$ & $\begin{array}{l}\text { Cerrado } \\
\text { sensu stricto }\end{array}$ & Total \\
\hline Necromys lasiurus & 59 & 26 & 34 & 51 & 11 & 181 \\
\hline Calomys expulsus & 22 & 2 & 0 & 1 & 5 & 30 \\
\hline Calomys tener & 6 & 2 & 0 & 0 & 5 & 13 \\
\hline Oxymycterus delator & 0 & 0 & 0 & 7 & 0 & 07 \\
\hline Cerradomys subflavus & 5 & 2 & 0 & 0 & 0 & 07 \\
\hline $\begin{array}{l}\text { Oligoryzomys } \\
\text { mattogrossae }\end{array}$ & 1 & 0 & 2 & 3 & 0 & 06 \\
\hline Cerradomys marinus & 0 & 0 & 4 & 0 & 0 & 04 \\
\hline Cerradomys maracajuensis & 1 & 0 & 1 & 0 & 0 & 02 \\
\hline Cerradomys scotti & 0 & 0 & 0 & 0 & 2 & 02 \\
\hline Pseudoryzomys simplex & 1 & 0 & 0 & 1 & 0 & 02 \\
\hline Oligoryzomys nigripes & 1 & 0 & 0 & 0 & 0 & 01 \\
\hline Calomys sp. & 1 & 0 & 0 & 0 & 0 & 01 \\
\hline Total & 98 & 32 & 41 & 63 & 24 & 258 \\
\hline
\end{tabular}

Table 3. Epidemiological data of HCPS patients and results of viral sequencing in an endemic area of Minas Gerais, Brazil, 2011-2012*

\begin{tabular}{llllll}
\hline \hline Sample & Municipality & Age, yr & Onset of symptoms & Data collection & Outcome \\
\hline LH_NAT & Rio Paranaíba & 40 & 16 Aug. 2012 & 19 Aug. 2012 & Survived \\
LH_206_12 & Uberlândia & 55 & 28 May 2012 & 3 June 2012 & Survived \\
LH_180_12 & Patrocínio & 30 & 25 Mar. 2012 & 28 Mar. 2012 & Died \\
LH_197_12 & São Tomás de Aquino & 31 & 27 Apr. 2012 & 2 May 2012 & Died \\
LH_212_12 & São Gotardo & 17 & 14 June 2012 & 18 June 2012 & Died \\
\hline \hline
\end{tabular}

* All the patients were male and were reactive in ELISA and positive by PCR. Genotype ARQV was found in all the patients.

of this study, located at a distance of about $261 \mathrm{~km}$ from these two municipalities. Pairwise sequence comparisons showed $91 \cdot 6-93 \cdot 7 \%$ nucleotide and 97.6$100 \%$ amino-acid identity between the samples of this study and Paranoa virus.

The LH-Nat (Genbank: KT257183), LH_212_12 (Genbank: KT257182) and LH_197_12 (Genbank: KT257180) samples were phylogenetically more closely related, forming a well-defined cluster in the three samples, with a well-supported cluster of $p p=1$. The first two came from patients in the municipalities of Rio Paranaíba, MG and São Gotardo, MG, respectively, located only $30 \mathrm{~km}$ from each other. However, the LH_197_12 sample came from a patient in São Tomás de Aquino, a municipality located $384 \mathrm{~km}$ from the municipalities where the other samples occurred. Pairwise comparisons of these sequences showed $95 \cdot 8-98 \cdot 2 \%$ nucleotide and $100 \%$ amino-acid identity.

According to a similarity analysis, the greatest divergence in our sequences was $12 \cdot 2 \%$ (nucleotide) and 2.4\% (amino acid) between LH_Nat (Rio Paranaíba) and the rodent sample LBCE_17849, and the lowest was $1.6 \%$ (nucleotide) and $1 \cdot 6 \%$ (amino acid) between rodent samples.

\section{DISCUSSION}

Climate is an important abiotic factor that influences the availability of food for rodents. The greater supply of food in the rainy season is directly associated with a higher reproductive rate of rodents. In this study, females showed a higher rate of pregnancy in the rainy season. This relationship leads to a higher 


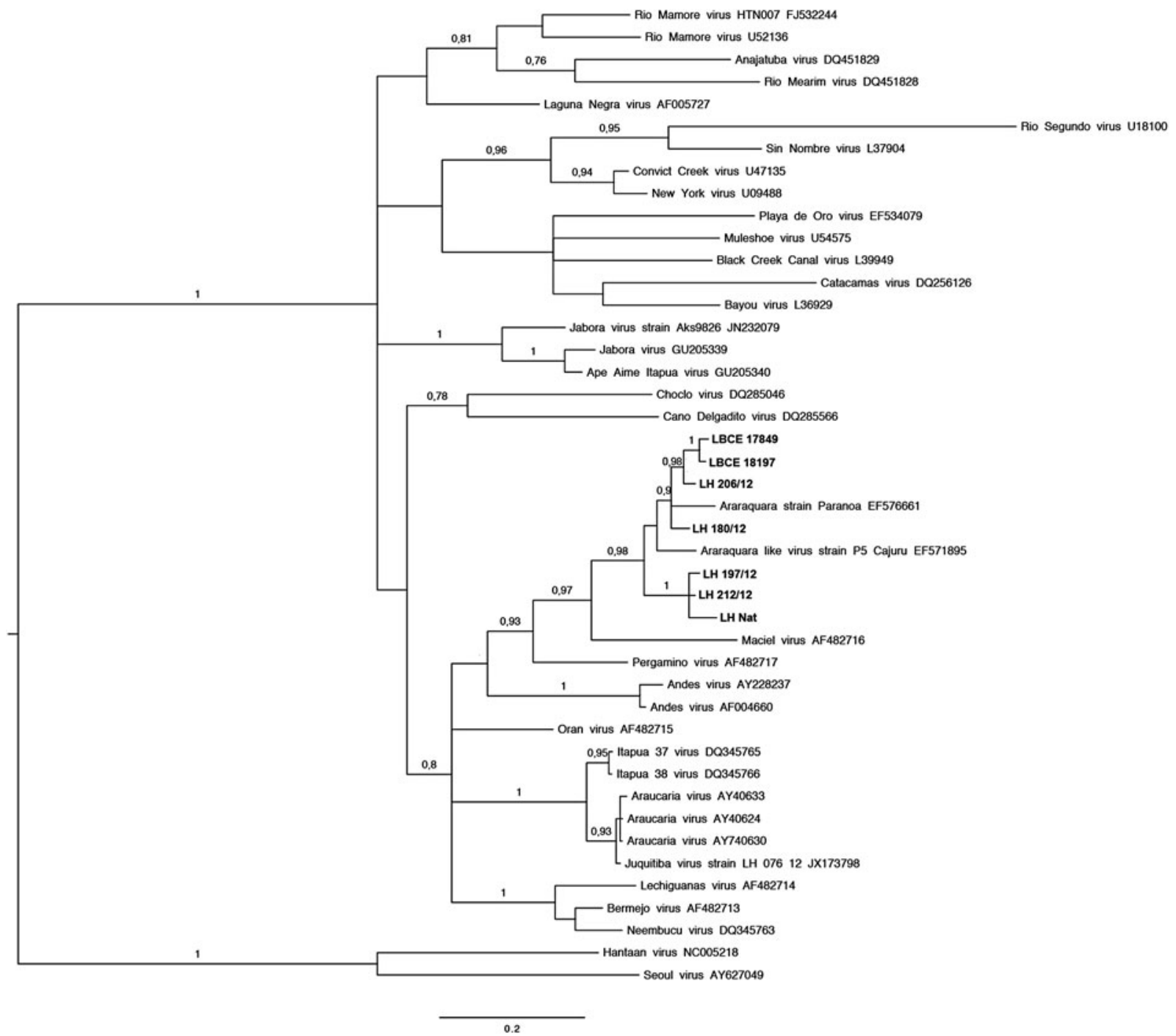

Fig. 2. Phylogenetic relationships among hantaviruses based on a Bayesian analysis of genetic distances generated from comparisons of a 382-nt fragment of the nucleocapsid protein gene sequences. Nucleotide sequences were analysed by a Bayesian analysis with MrBayes version 3.1.2, using a general time reversible $G$ model. The scale bar indicates the evolutionary distance of $0 \cdot 2$ substitutions per site. The numerical value at the node indicates the posterior probability (pp) replicates that supported the interior branch. The branch labels include GenBank accession number and viral species, genotype or strain.

proportion of juveniles in the dry season, resulting in an increased number of captures, and of adults in the rainy season, which have a higher prevalence of hantavirus. The population dynamics of these rodents is consistent with the results obtained in other studies $[32,33]$.

Eleven taxa were identified to the species level and two to the generic level, all belonging to the subfamily Sigmodontinae. This information reflects the territory in which the rodents were captured, in wild environments far away from peri-urban areas.

$N$. lasiurus was the most prevalent $(70 \cdot 1 \%)$ in the captured species. These rodents are aggressive and generally dominate the area that they infest [34]. The general behaviour of $N$. lasiurus makes this species highly adaptable to man-made environments and to less complex ecosystems, especially grassy areas (Brachiaria spp.). $N$. lasiurus specimens represented $>30 \%$ of the individuals captured in most of the areas sampled in the Cerrado biome [35].

In our study, $N$. lasiurus represented at least $50 \%$ of the captured specimens (min-max: 50-83.7\%). The higher prevalence of $N$. lasiurus in this study compared to earlier reports can be directly attributed to the intense process of degradation this biome has undergone in recent decades, with large areas planted 
with monoculture crops, which have favoured this species in interspecific competition with other rodents, mostly habitat specialists $[16,34]$. The ecological pattern of $N$. lasiurus associated with deep anthropogenic changes in this biome greatly increases the chances of contact between humans and infected rodents, mainly due to the potential increase in population density of these rodents and the narrowing of environments shared with humans [36].

The rodent $O$. mattogrossae was captured in three phytophysiognomies. This rodent is associated with the hantavirus Anajatuba in northeastern Brazil and has also recently been considered a reservoir of JUQV in the Cerrado biome. In southern Brazil and in the state of São Paulo, the main reservoir of this virus is the species $O$. nigripes, which was also found in this study $[15,37,38]$. The species of the genus Calomys found in this study are not associated with any hantavirus, despite a report of ARQV that was sequenced from a lung sample from a $C$. tener specimen in the state of São Paulo. However, the authors attributed the infection to a likely spillover of the virus of $N$. lasiurus [39].

The seroreactive rodents had scars on their ears and/or tail. The presence of scars in rodents may be associated with seroreactivity to hantavirus in reservoirs, and studies have shown that the prevalence of infection is higher in adult males than in females and juveniles [32, 33].

Since the first record of a case of HCPS in the state of Minas Gerais in 1998, only three molecular studies in Brazil have included human samples of HCPS cases from these regions, with 15 samples analysed phylogenetically, collected in the municipalities of Araxá (1), Patrocínio (4), Uberlândia (2), Uberaba (4), Patos de Minas (1), São Tomás de Aquino (1), São Sebastião do Paraíso (1) and Passos (1). In these studies, the cases of HCPS were associated primarily with ARQV [6, 12, 38]. However, evidence of the circulation of JUQV, as well as a highly divergent strain of ARQV and JUQV, has been reported in humans and rodents, respectively, in these areas [6, 12]. In one of these studies, a virus related to JUQV was reported in human serum samples of from the municipalities of Uberaba, Patrocínio, São Sebastião do Paraíso and Passos [12]. In our study, we found only the ARQV genotype in the samples from the municipalities of Patrocínio and São Tomás de Aquino, a municipality located $23 \mathrm{~km}$ from the municipality of São Sebastião do Paraíso. In the same study in which JUQV was reported in the state of Minas
Gerais, ARQV was also reported in the municipalities of Passos, Teófilo Otoni, Uberlândia, Uberaba, Patos de Minas, São Tomás de Aquino, Sete Lagoas and Piumhi. These data corroborate the findings of our study in Uberlândia, where only the ARQV genotype was found.

JUQV is one of the most widely distributed hantaviruses found in South America and has been detected in O. mattogrossae, O. nigripes, Akodon montensis, Oxymycterus judex, Akodon paranaensis, O. nigripes, Oryzomys sp. and $O$. fornesi rodents in Brazil, Argentina, Paraguay and Uruguay [15] JUQV is often related to HCPS cases occurring in southern Brazil and in the state of São Paulo [7, 12, 38]. However, the rodents $O$. mattogrossae and $O$. nigripes also occur in the Cerrado biome in the state of Minas Gerais [20]. Five specimens of $O$. nigripes were found in a study of hantavirus reservoirs in the municipality of Uberlândia, but they were not hantavirus seropositive [33]. In the present study, one $O$. nigripes specimen and six $O$. mattogrossae specimens were captured, all of them seronegative for hantavirus. It should be noted that the JUQV genome was recently sequenced from specimens of $O$. mattogrossae from the Cerrado biome in the state of Mato Grosso do Sul, confirming the complexity of the hantavirus-wild rodent interaction [15].

A highly divergent strain of the ARQV and JUQV genotypes was recently identified in $N$. lasiurus in the municipality São Gotardo, MG, and the authors sequenced ARQV genotype in two other $N$. lasiurus specimens captured in the same municipality [12]. In our study, only the ARQV genotype was identified in a human sample from this municipality, as well as in one from Rio Paranaíba, MG, located $30 \mathrm{~km}$ from São Gotardo, MG.

In a phylogenetic study of hantavirus genotypes in samples from southern and southeastern Brazil, the viral sequence of a patient with HCPS from the municipality of Patrocínio, MG showed the highest divergence in the members of the Araraquara clade $(16.7 \%)$ [38]. In this same study, but in the municipality of Uberlândia, another viral sequence extracted from the lungs of a $N$. lasiurus rodent also proved highly divergent from the other genotypes of the Andes clade. In the phylogenetic analysis of our study, the LH_180_12 sample of the patient from Patrocínio who died, along with the LH_206_12 sample of a patient with HCPS in Uberlândia, were also the most divergent between clade samples. These data indicate that genetic diversity of ARQV is greater than previously believed. 
The samples analysed in this study came from an area whose natural ecosystems are in large part degraded as a result of intensive farming and cattle ranching. The environmental and demographic changes that have taken place in recent decades have probably affected the ecology of wild rodents, facilitating the occurrence of human hantavirus infections and the emergence of HCPS in this region, particularly ARQV [12]. Samples identified with ARQV analysed in this study were distributed $\sim 400 \mathrm{~km}$ from one another.

Higher case-fatality rates are observed in regions where the ARQV genotype is endemic in Brazil than in areas where JUQV occurs [12]. In our study, the case-fatality rate of $60 \%$ of HCPS cases provides evidence that ARQV is the most prevalent genotype in the study area. Although other studies are necessary to determined which factors influence the outcome of HCPS cases caused by ARQV or JUQV, the occurrence of different genotypes/viral variants may partly explain the clinical spectrum of hantavirus infection, which ranges from asymptomatic infections to cases with high fatality rates $[5,36]$.

This study reported the circulation of a single genotype, i.e. ARQV, in the most endemic area of the state of Minas Gerais, Brazil, where N. lasiurus is the predominant species. However, it is reasonable to assume that other reservoir hosts of hantavirus can be associated with human disease in this region, due to the presence of JUQV associated with HCPS cases and Oligoryzomys species. The environmental changes that have occurred in the Cerrado biome in recent decades have favoured $N$. lasiurus in interspecific competition of habitats, which, in turn, has considerably increased the risk of contact of these rodents with humans. All our data corroborate the definition of $N$. lasiurus as the main hantavirus reservoir in the Cerrado biome [38].

\section{SUPPLEMENTARY MATERIAL}

For supplementary material accompanying this paper visit http://dx.doi.org/10.1017/S095026881500237X.

\section{ACKNOWLEDGEMENTS}

The authors thank Matias Pablo Juan Szabó for assistance and technical support.

This work was supported by CNPq Papes FIOCRUZ V 403601/2008-8 and Papes FIOCRUZ VI 407664/2012-2 (Brazil).

\section{DECLARATION OF INTEREST}

None.

\section{REFERENCES}

1. Musser GG, Carleton MD. Family Cricetidae. In: Wilson DE, Reeder DM, eds. Mammal Species of the World: a Taxonomic and Geographic Reference, 3rd edn. Baltimore: Johns Hopkins University Press, 2005, pp. 955-1189.

2. Nichol ST, et al. Family Bunyaviridae. In: Fauquet CM, Mayo MA, Maniloff J, et al., eds. Virus Taxonomy: Eighth Report of the International Committee on Taxonomy of Viruses. San Diego: Elsevier Academic Press, 2005, pp. 695-716.

3. Oliveira RC, et al. Hantavirus reservoirs: current status with an emphasis on data from Brazil. Viruses 2014; 6: 1929-1973.

4. Araújo $\mathbf{J}$, et al. Detection of hantavirus in bats from remaining rain forest in São Paulo, Brazil. $B M C$ Research Notes 2012; 215: 690.

5. Limongi JE, et al. Cross-sectional survey of hantavirus infection, Brazil. Emerging Infectious Diseases 2009; 15: 1981-1983.

6. Araujo $\mathbf{J}$, et al. Co-circulation in a single biome of the Juquitiba and Araraquara hantavirus detected in human sera in a sub-tropical region of Brazil. Journal of Medical Virology 2015; 87: 725-732.

7. Jonsson CB, Figueiredo LTM, Vapalahti O. A global perspective on hantavirus ecology, epidemiology, and disease. Clinical Microbiology Reviews 2010; 23: 412 441.

8. Oliveira RC, et al. Rio Mamoré virus and hantavirus pulmonary syndrome, Brazil. Emerging Infectious Diseases 2014; 20: 1568-1570.

9. Souza WM, Figueiredo LTM. Analysis of the nucleocapsid gene brings new insights to the classification of Sigmodontinae-borne hantaviruses. Archives of Virology 2014; 159: 2475-2477.

10. Firth C, et al. Diversity and distribution of hantaviruses in South America. Journal of Virology 2012; 86: 13756 13766.

11. Melo-Silva CR, et al. Characterization of hantaviruses circulating in Central Brazil. Infection, Genetics and Evolution 2009; 9: 241-247.

12. Figueiredo LTM, et al. Hantavirus pulmonary syndrome, Central Plateau, Southeastern, and Southern Brazil. Emerging Infectious Diseases 2009; 15: 561-567.

13. Figueiredo LTM, et al. Hantaviruses and cardiopulmonary syndrome in South America. Virus Research 2014; 187: 43-54.

14. Weksler M, Bonvicino CR. Genus Oligoryzomys Bangs, 1900. In: Patton JL, Pardiñas UFJ, D’Elía G, eds. Mammals of South America, vol. 2, Rodents. Chicago: The University of Chicago Press, 2015, pp. 1305-1375.

15. Guterres A, et al. Characterization of Juquitiba virus in Oligoryzomys fornesi from Brazilian Cerrado. Viruses 2014; 6: 1473-1482. 
16. Ribeiro JF, Walter BMT. The main phytophysiognomies of Cerrado Biome. In: Sano SM, Almeida SP, Ribeiro JF, eds. Ecologia e Flora. Brasília: Embrapa, 2008, pp. 152-212.

17. Mills JN, et al. Methods for Trapping and Sampling Small Mammals for Virologic Testing. Atlanta: Centers for Disease Control and Prevention, 1995, pp. 201.

18. Pachaly JR, Brito HFV. Interspecific allometric scaling. In: Fowler ME, Cubas ZS, eds. Biology, Medicine, and Surgery of South American Wild Animals. Ames, IA: Iowa State University Press, 2001, pp. 475-481.

19. Mills JN, et al. A longitudinal study of hantavirus infection in three sympatric reservoir species in agroecosystems on the Argentine Pampa. Vector Borne and Zoonotic Diseases 2007; 7: 229-240.

20. Bonvicino CR, Oliveira JA, Dandrea PS. Guide of the rodents of Brazil with keys for genera, based on external characters. Rio de Janeiro: Centro Panamericano de Febre Aftosa-OPAS/OMS, 2008, pp. 120.

21. Bonvicino CR, et al. The chromosomes of Nectomys (Rodentia, Cricetidae) with $2 \mathrm{n}=52,2 \mathrm{n}=56$, and interspecific hybrids $(2 \mathrm{n}=54)$. Cytogenetics and Cell Genetics 1996; 73: 190-193.

22. Sambrook J, Fritsch EF, Maniatis T. Molecular Cloning: A Laboratory Manual. New York: Cold Spring Harbor Laboratory Press, 1989, pp. 230.

23. Irwin DM, Kocher TD, Wilson AC. Evolution of the cytochrome b gene of mammals. Journal of Molecular Evolution 1991; 32: 128-144.

24. Smith MF, Patton JL. Variation in mitochondrial cytochrome $b$ sequence in natural populations of South American Akodontine rodents (Muridae: Sigmodontinae). Molecular Biology and Evolution 1991; 8: 85-103.

25. Cassens I, et al. Mitochondrial DNA variation in the European otter (Lutralutra) and the use of spatial autocorrelation analysis in conservation. Journal of Heredity 2000; 91: 31-35.

26. Raboni SM, et al. Hantavirus infection in Brazil: development and evaluation of an enzyme immunoassay and immunoblotting based on $\mathrm{N}$ recombinant protein. Diagnostic Microbiology and Infectious Disease 2007; 58: 89-97.

27. Figueiredo LTM, et al. Expression of a hantavirus $\mathrm{N}$ protein and its efficacy as antigen in immune assays.
Brazilian Journal of Medical and Biological Research 2008; 41: 596-599.

28. Figueiredo LTM, et al. Evaluation of an enzyme-linked immunosorbent assay based on Araraquara virus recombinant nucleocapsid protein. American Journal of Tropical Medicine and Hygiene 2009; 81: 273-276

29. Guterres A, et al. Phylogenetic analysis of the S segment from Juquitiba hantavirus: identification of two distinct lineages in Oligoryzomys nigripes. Infection, Genetics and Evolution 2013; 18: 262-268.

30. Tamura K, et al. MEGA5: Molecular Evolutionary Genetics Analysis using maximum likelihood, evolutionary distance, and maximum parsimony methods. Molecular Biology and Evolution 2010; 28: 2731-2739.

31. Ronquist F, Huelsenbeck JP. MrBayes 3: Bayesian phylogenetic inference under mixed models. Bioinformatics 2003; 19: 1572-1574.

32. Teixeira BR, et al. Population ecology of hantavirus rodent hosts in southern Brazil. American Journal of Tropical Medicine and Hygiene 2014; 91: 249-257.

33. Limongi JE, et al. Serological survey of hantavirus in rodents in Uberlândia, Minas Gerais, Brazil. Revista do Instituto de Medicina Tropical de São Paulo 2013; 55: 155-158.

34. Streilen KE. Ecology of small mammals in the Semiarid Brazilian Caatinga I. Climate and faunal composition. Annals of Carnegie Museum 1982; 51: 79-107.

35. Marinho-Filho J, et al. Diversity standards and small mammal numbers: conservation of the cerrado biodiversity. Anais da Academia Brasileira de Ciências 1994; 66: 49-156.

36. Limongi JE, et al. Hantavirus cardiopulmonary syndrome in the Triângulo Mineiro and Alto Paranaíba regions, State of Minas Gerais, 1998-2005: clinical-epidemiological aspects of 23 cases. Revista da Sociedade Brasileira de Medicina Tropical 2007; 40: 295-299.

37. Rosa EST, et al. Hantaviruses and hantavirus pulmonary syndrome, Maranhão, Brazil. Emerging Infectious Diseases 2010; 16: 1952-1955.

38. Suzuki A, et al. Identifying rodent hantavirus reservoirs, Brazil. Emerging Infectious Diseases 2004; 10: $2127-$ 2134.

39. Figueiredo GG, et al. Diagnosis of hantavirus infection in humans and rodents in Ribeirão Preto, State of São Paulo, Brazil. Revista da Sociedade Brasileira de Medicina Tropical 2010; 43: 348-354. 